\title{
Aureobasidium iranianum, a new species on bamboo from Iran
}

\author{
Arzanlou $\mathbf{M}^{* 1}$, Khodaei $\mathbf{S}^{2}$ \\ ${ }^{1}$ Assistant Professor of Plant Pathology and Mycology, Plant Protection Department, Faculty of Agriculture, University \\ of Tabriz, PO Box: 5166614766, Iran. \\ ${ }^{2}$ MSc Student of Plant Pathology, Plant Protection Department, Faculty of Agriculture, University of Tabriz, PO Box: \\ 5166614766, Iran.
}

Arzanlou M, Khodaei S 2012 - Aureobasidium iranianum, a new species on bamboo from Iran. Mycosphere 3(4), 404-408, Doi 10.5943 /mycosphere/3/4/2

An endophytic species of black yeasts, Aureobasidium iranianum, is described and illustrated from bamboo stem in Iran using morphological as well as sequence data from the ITS-rDNA region. The species can be distinguished from other Aureobasidium species by the abundant production of pigmented arthroconidia in culture and ITS barcode.

Key words - black yeast - ITS - taxonomy

\section{Article Information}

Received 8 June 2012

Accepted 20 June 2012

Published online 6 July 2012

*Corresponding author: Mahdi Arzanlou - e-mail - Arzanlou@ hotmail.com

\section{Introduction}

The genus Aureobasidium Viala \& Boyer is a yeast-like deuteromycete that accommodates species with synchronous conidium production and hyaline conidiogenous cells (Hermanides-Nijhof 1977, Zalar et al. 2008). Members of this genus produce onecelled conidia of various shapes from hyaline and terminal, lateral or intercalary conidiogenous cells (Hermanides-Nijhof 1977). Species of the genus are ubiquitous and found on different habitats such as plant materials (phyllosphere, plant debris, bark, roots, fruits, wood), water, marine sediments, marshland, soil, air, skin, nails, stone, glass and in the clinical laboratory as a contaminant or human pathogen (Hermanides-Nijhof 1977, de Hoog \& Yurlova 1994, de Hoog et al. 1999, 2000, Urzi et al. 1999). Members of this genus have diverse life styles as saprophytes, plant associated endophytes or pathogens and opportunistic human pathogens (Andrews et al. 2002, Loncaric et al. 2008, Martini et al. 2009). Aureobasidum pullulans (De Bary) Arnaud, the type species of the genus, is well known for its commercial significance as a producer of pullulan, a biodegradable extracellular polysaccharide (Singh et al. 2008, Zalar et al. 2008) and also has been considered as a potential biocontrol agent of post harvest plant pathogens (e.g., Botrytis cinerea and Penicillium expansum), by means of different antagonistic strategies such as competing for nutrients and space and producing numerous compounds including pectolytic enzymes, antimicrobial metabolites and high-molecular-weight polysaccharides (Castoria et al. 2001, Dugan et al. 2002, Schena et al. 1999, 2003, Seibold et al. 2004, Elmer \& Reglinski 2006, Felice et al. 2008, Zalar et al. 2008, Martini et al. 2009).

During a study of microfungi associated with bamboo species in southern Iran (Bushehr Province) an endophytic black yeast fungus was isolated from apparently healthy bamboo stems. The fungus was identified as a new species of the genus Aureobasidium based on phenotypic features and sequence data from ITS-rDNA region. 


\section{Methods}

\section{Collection of isolates, morphological and cultural studies}

Bamboo stems were sampled from southern parts of Iran, cut into small pieces, surface sterilized with $70 \%$ ethanol, rinsed two times with sterilized distilled water, dried on sterile filter paper, and plated on acidified malt extract agar (MEA; Himedia, India). Pure cultures were established by transferring emergent hyphal tips to a fresh MEA plate. The cultures were deposited in the living Culture Collection of Tabriz University (CCTU), Tabriz, Iran. The fungus was sub-cultured on MEA, and incubated at $25^{\circ} \mathrm{C}$ in the dark. After 1 week of incubation, cultural and microscopic features were studied. Measurements and microphotographs were taken from slide mounts in lactic acid. Thirty measurements were made for each microscopic structure and 95th percentiles were defined for all measurements with the extremes given in parentheses.

\section{DNA extraction, amplifcation and phylogenetic analysis}

Fungal isolates were cultured on MEA at $25^{\circ} \mathrm{C}$ in dark. After 7 days, genomic DNA was extracted using the method of Moller et al. (1992). The primers ITS1 and ITS4 (White et al. 1990) were used to amplify part (ITS) of the nuclear rRNA operon spanning the 3 ' end of the 18S rRNA gene, the first internal transcribed spacer (ITS1), the 5.8S rRNA gene, the second ITS region and the 5' end of the $28 \mathrm{~S}$ rRNA gene. The reaction mixture and PCR conditions were the same as Arzanlou \& Khodaei (2012a, b) and Arzanlou et al. (2012). Sequences were compared with the sequences available in NCBI's GenBank nucleotide (nr) database using a megablast search.

\section{Results}

\section{DNA Phylogeny}

Based on megablast search of ITS sequence against GenBank nucleotide database, the closest hits were for Aureobasidium pullulans isolates with $97 \%$ maximal identity.

\section{Morphology}

Aureobasidium iranianum Arzanlou \& S. Khodaei sp. nov. Figs $1-8$

Mycobank: MB800705

Etymology - epithet derived from the country of origin.

Diagnosis - distinguished from other known species of the genus Aureobasidium by abundant production of darkly pigmented arthroconidia and conidial dimensions.

Colonies on MEA moderately fast growing, attaining diameter of $20 \mathrm{~mm}$ in 7 days, spreading, smooth, flat, rapidly turning to olivaceous black, with dark green, irregular margins, covered with slimy masses of conidia (Fig 1). Mycelium immersed, no aerial mycelium. Hyphae subhyaline, smooth, thinwalled, 3-8 $\mu \mathrm{m}$ wide, septate, soon becoming brown, thick-walled. Conidiogenous cells undifferentiated, hyaline, intercalary or rarely terminal. Conidia blastic, produced simultaneously in dense clusters from small denticles, $(5-) 7-9(-14) \times 3-6 \mu \mathrm{m}$, hyaline to dark brown, smooth, one-celled, thin-walled, with several guttules, variable in shape and size, ellipsoidal to spherical to ovoid, straight, rarely slightly curved, with rounded to subtruncate base and a flat basal hilum. Secondary conidia produced by terminal or sub-terminal, mono- or bipolar budding of primary conidia. Arthroconidia frequently formed, dark, 1- to 2- or rarely 4-celled, (5-)1012(-19) $\times(4-) 6-7 \quad(-11) \mu \mathrm{m}$. Conidia and secondary conidia cicatrized at detachment. No endoconidia observed (Figs 2-8).

Material examined - IRAN, Bushehr Province, Kangan, Assaluyeh, stems of Bambusa sp. ( Poaceae), 10 June, 2009 dried culture preserved as CCTU H- 268 holotype (culture ex-type $=$ CCTU 268).

\section{Discussion}

The genus Aureobasidium belongs to the family Dothioraceae (order Dothideales, class Dothidiomycetes, Ascomycota) (Schoch et al. 2006, Zalar et al. 2008). The genus is characterized by holoblastic and synchronous conidium formation. There are several other mitosporic fungi with phylogenetic affinity to the order Dothideales viz., Kabatiella Bubák, 

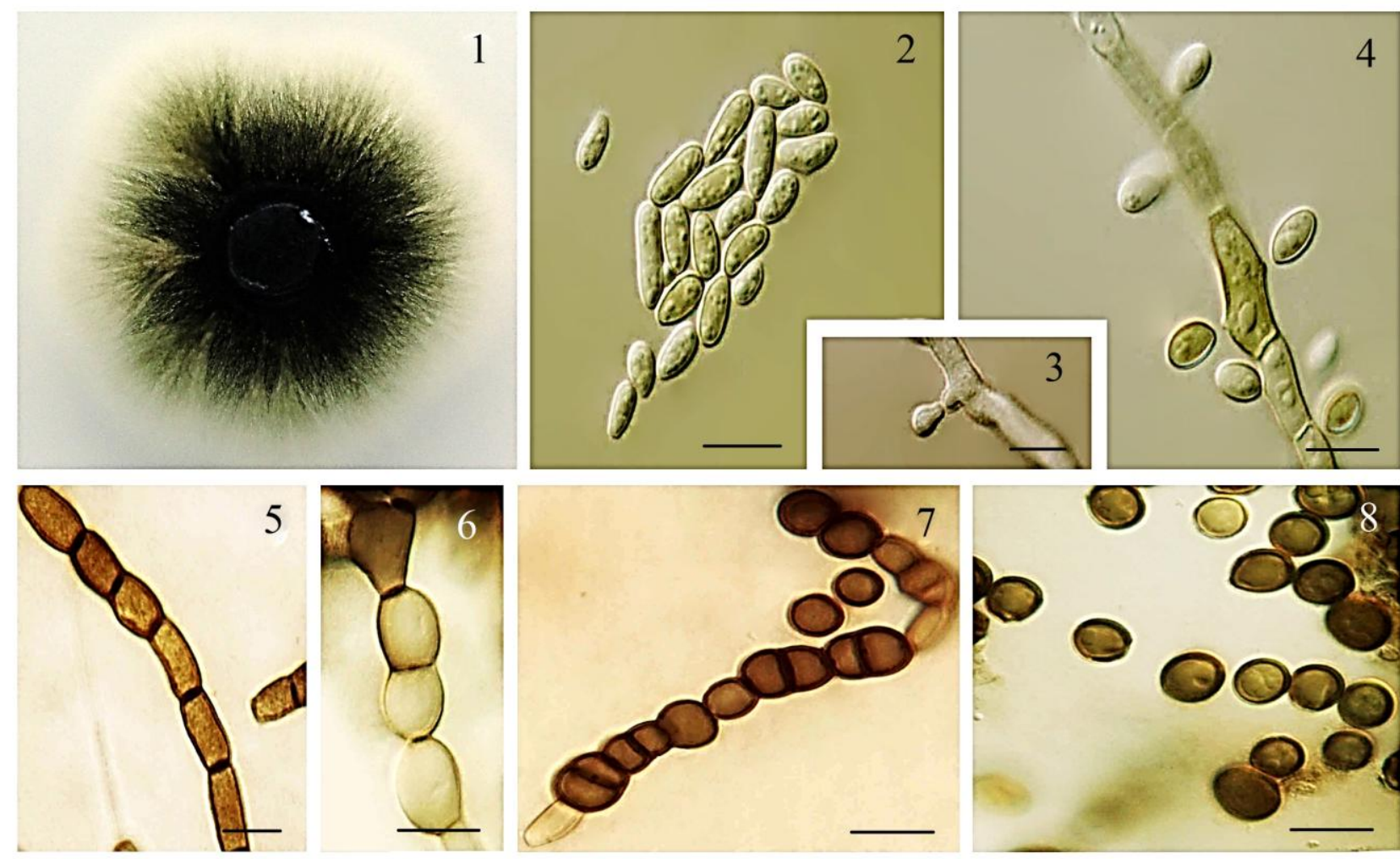

Figs 1-8 - Aureobasidium iranianum 1 7-day-old colony on MEA 2 Conidia 3, 4 Conidiogenous cells and conidia 5 Dark hyphae 6, 7,8 Arthroconidia - Bars $=10 \mu \mathrm{m}$.

Hormonema Lagerb. \& Melin and Selenophoma Maire (Yurlova et al. 1996, 1999, Zalar et al. 2008). The genus Kabatiella is a plant pathogen causing spot on specific plant species. Species of this genus are considered to have a narrow host range. The members of this genus are characterized by their sporodochial conidiomata on host plant leaves. However, in culture it is very difficult to distinguish Kabatiella from Aureobasidium as sporodochia are usually not formed or fall apart and micromorphology is similar to Aureobasidium (Zalar et al. 2008). Many Kabatiella species are known only from the sporodochial anamorph on the host plant and there is no living culture available for these species to determine their phylogeny. Kabatiella has been considered as a synonym of Aureobasidium by Hermanides-Nijhof (1977) who classified all Kabatiella species in Aureobasidium (Zalar et al. 2008). A phylogeny inferred from LSU sequence data of $A$. pullulans and its varieties revealed phylogenetic affinity of Kabatiella spp. with A. pullulans (Zalar et al. 2008). However, Kabatiella has been listed as a separate genus by Seifert et al. (2011); according to them Kabatiella is morphologically distinct from Aureobasidium. Most of the species in the genus Kabatiella have sickle-shaped conidia, a feature which can be used to make a distinction between the two genera (Zalar et al. 2008). More isolates are needed to explore phylogeny of these morphologically similar genera.

Aureobasidium iranianum was identified as a member of the genus Aureobasidium by morphological characteristics of conidiogenous cell and conidia. Conidiogenous cells are undifferentiated from vegetative hyphae, hyaline, intercalary or rarely terminal (Yurlova et al. 1996, 1999, Zalar et al. 2008). Conidia are produced simultaneously in dense clusters from small denticles. A. iranianum produces 1-celled conidia which are hyaline or brown. The formation of brown conidia have been also observed in $A$. pullulans var. melanogenum isolates, originating either by transfer of hyaline conidia or disarticulating dark brown hyphae (arthroconidia). Formation of brown conidia occurred in A. iranianum; the first type of brown conidia (transfer of hyaline conidia) were always 1-celled, the second type (arthroconidia) were 1- to 2- or rarely 4-celled cells produced in abundance. 
A. iranianum can be easily distinguished from $A$. pullulans var. melanogenum by its conidial dimensions, which in both cases (blastoconidia and arthroconidia) are larger than those of A. pullulans var. melanogenum. Besides, in A. pullulans var. melanogenum percurrent expansion of the conidiogenous cells has also been observed, which was not observed in $A$. iranianum. Percurrent expansion for the conidiogenous cells is characteristics of the genus Hormonema (Zalar et al. 2008).

The identity of Aureobasidium iranianum as new species was further confirmed by sequence data from ITS-rDNA region. ITS sequence showed $97 \%$ similarity with A. pullulans isolates from GenBank. However there was no ITS sequence available for the other species of this genus in GenBank. A comparison made by Prof. Sybren de Hood at his private sequence database of black yeast fungi, housed at CBS-Fungal Biodiversity Centre in Utrecht, The Netherlands revealed that $A$. iranianum clusters outside $A$. pullulans and its varieties. The ITS sequence for CCTU 268 is available with the GenBank accession number: JX205092. The ecology of $A$. iranianum remains to be studied.

\section{Acknowledgements}

The authors are grateful to the Research Deputy of the University of Tabriz and the Studienstiftung Mykologie for financial support.

\section{References}

Andrews JH, Spear RN, Nordheim EV. 2002 Population biology of Aureobasidium pullulans on apple leaf surface. Canadian Journal of Microbiology 48, 500-513.

Arzanlou M, Khodaei S, Saadati Bezdi M. 2012 - Occurrence of Chaetomidium arxii on sunn pest in Iran. Mycosphere 3, 234-239.

Arzanlou M, Khodaei S. 2012a - Phenotypic and molecular characterization of Chaetopyrena penicillata from Iran with description of a hyphomycete synanamorph. Mycosphere 3, 73-77.

Arzanlou M, Khodaei S. 2012b - Bipolaris spicifera isolates with unusual conidial germination pattern on sunflower from Iran. Plant Pathology \& Quarantine 2, 64-68.

Castoria R, de Curtis F, Lima G, Caputo L, Pacifico S, de Cicco V. 2001Aureobasidium pullulans (LS-30) an antagonist of postharvest pathogens of fruits: study on its modes of action. Postharvest Biology and Technology 22, 7-17.

de Hoog GS, Guarro J, Gené J, Figueras MJ. 2000 - Atlas of Clinical Fungi, 2nd ed. Centraalbureau voor Schimmelcultures / Universitat Rovira i Virgili, Utrecht / Reus, 1126 pp.

de Hoog GS, Yurlova NA. 1994 Conidiogenesis, nutritional physiology and taxonomy of Aureobasidium and Hormonema. Antonie van Leeuwenhoek 65, 41-54.

de Hoog GS, Zalar P, Urzì C, de Leo F, Yurlova NA, Sterflinger K. 1999 Relationships of dothideaceous black yeasts and meristematic fungi based on 5.8S and ITS2 rDNA sequence comparison. Studies in Mycology 43, 31-37.

Dugan FM, Lupien SL, Grove GG. 2002 Incidence, aggressiveness and in planta interactions of Botrytis cinerea and other filamentous fungi quiescent in grape berries and dormant buds in Central Washington State. Journal of Phytopathology 150, 375-381.

Elmer PAG, Reglinski T. 2006 Biosuppression of Botrytis cinerea in grapes. Plant Pathology 55, 155-177.

Felice DV de, Solfrizzo M, De Curtis F, Lima G, Visconti A, Castoria R. 2008 Strains of Aureobasidium pullulans can lower ochratoxin A contamination in wine grapes. Phytopathology 98, 12611270.

Hermanides-Nijhof EJ. 1977 - Aureobasidium and allied genera. Studies in Mycology $15,141-222$.

Loncaric I, Donat C, Antlinger B, Oberlerchner JT, Heissenberger B, Moosbeckhofer R. 2008 - Strain-specific detection of two Aureobasidium pullulans strains, fungal biocontrol agents of fire blight by new, 
developed multiplex-PCR. Journal of Applied Microbiology 104, 1433-1441.

Martini M, Musetti R, Grisan S, Polizzotto R, Borselli S, Pavan F, Osler R. 2009 DNA-dependent detection of the grapevine fungal endophytes Aureobasidium pullulans and Epicoccum nigrum. Plant Disease 93, 993-998.

Moller EM, Bahnweg G, Geiger HH. 1992- A simple and efficient protocol for isolation of high molecular weight DNA from filamentous fungi, fruit bodies, and infected plant tissues. Nuclear Acid Research 20, 6115-6116.

Schena L, Ippolito A, Zahavi T, Cohen L, Nigro F, Droby S. 1999 - Genetic diversity and biocontrol activity of Aureobasidium pullulans isolates against postharvest rots. Postharvest Biology and Technology 17, 189-199.

Schena L, Nigro F, Pentimone I, Ligorio A, Ippolito A. 2003- Control of postharvest rots of sweet cherries and table grapes with endophytic isolates of Aureobasidium pullulans. Postharvest Biology and Technology 30, 209-220.

Schoch CL, Shoemaker RA, Seifert KA, Hambleton S, Spatafora JW, Crous PW. 2006 - A multigene phylogeny of the Dothideomycetes using four nuclear loci. Mycologia 98, 1041-1052.

Seibold A, Fried A, Kunz S, Moltmann E, Lange E, Jelkmann W. 2004 - Yeasts as antagonists against fire blight. EPPO Bulletin 34, 389-390.

Seifert K, Morgan-Jones G, Gams W, Kendrick B. $2011-$ The Genera of Hyphomycetes.
CBS Biodiversity Series no. 9, 1-997. CBS-KNAW Fungal Biodiversity Centre, Utrecht, Netherlands.

Singh RS, Saini GK, Kennedy JF. 2008 Pullulan: microbial sources, production and applications. Carbohydrate Polymers 73, 515-531.

Urzì C, De Leo F, Lo Passo C, Criseo G. 1999 - Intra-specific diversity of Aureobasidium pullulans strains isolated from rocks and other habitats assessed by physiological methods and by random amplified polymorphic DNA (RAPD). Journal of Microbiological Methods 36, 95-105.

White TJ, Bruns TD, Lee SB, Taylor JW. 1990 - Amplification and sequencing of fungal ribosomal RNA genes for phylogenetics, pp. 315-322. In: PCRProtocols and Applications - A Laboratory Manual (Innis N, Gelfand D, Sninsky J, White TC, eds). Academic Press, New York.

Yurlova NA, de Hoog GS, Gerrits van den Ende AHG. 1999 - Taxonomy of Aureobasidium and allied genera. Studies in Mycology 43, 63-69.

Yurlova NA, Uijthof JM, de Hoog GS. 1996 Distinction of species in Aureobasidium and related genera by PCR-ribotyping. Antonie van Leeuwenhoek 69, 323329.

Zalar P, Gostinčar C, Hoog, GS de, Uršič V, Sudhadham M, Gunde-Cimerman N. 2008 - Redefinition of Aureobasidium pullulans and its varieties. Studies in Mycology 61, 21-38. 